\title{
REPARAR MIÚDO, NARRAR KÉKERÉ Notas sobre nossa fotoetnopoética com crianças de terreiros
}

Stela Guedes Caputo $^{(*)}$

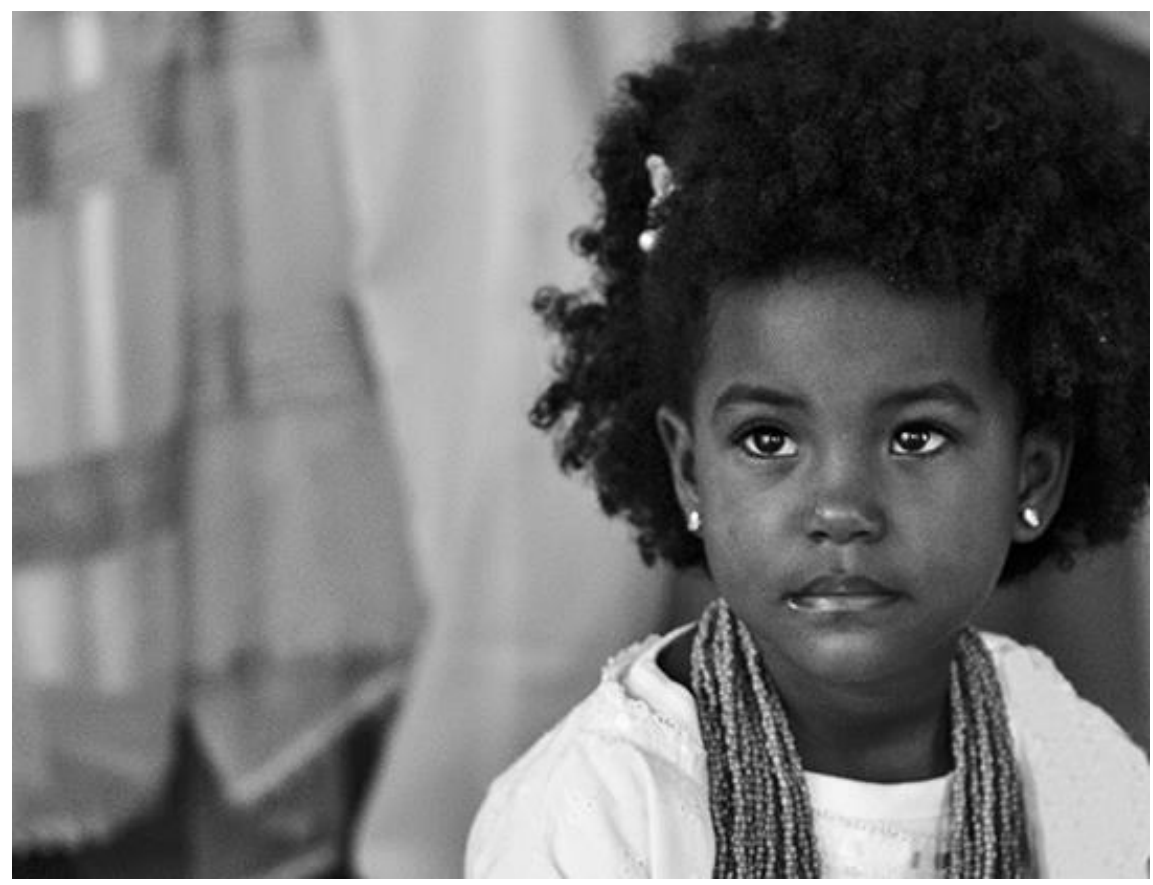

\section{1. "O terreiro é o mundo ficando mais bonito"}

\section{Ėmí Kékeré, Émí Ọmodé: as crianças falam primeiro}

A fala que dá título a essa introdução é de Mene Viana Cardoso, de 3 anos, soprada no dia 5 de agosto de 2017. Havia um barco de três iniciados saindo naquela tarde no Ilè Aṣé Omi Laare İyá Sagbál, um terreiro de candomblé, em Santa Cruz da Serra, Duque de Caxias, na Baixada Fluminese. Um barco de iaôs, ou ìyàwo ${ }^{2}$, é um conjunto de pessoas que se inicia ao mesmo tempo. Como esse terreiro é onde sou iniciada, me dividia entre as funções de filha de santo e as funções da pesquisa de campo, o que nunca é fácil. Cumprimentei o Exu do portão, tomei banho de àgbo (banho ritual), troquei de roupa, bati cabeça em cada lugar necessário. Tomei bença ao pai de santo,

\footnotetext{
${ }^{(*)}$ Professora Adjunta da Faculdade de Educação e do PROPED-UERJ. Coordenadora do Kékeré.

${ }^{1}$ Candomblé Ketu, dirigido pelo Babalorixá Daniel de Iemajá. Todas os terreiros desse artigo são Ketu.

${ }^{2}$ Sempre que achar necessário elou possível, utilizarei palavras em yòrùbá na forma como se escrevem. Beniste (2006) explica que em algumas letras se usa um ponto embaixo. $O$ e E dão um som aberto; sem ele o som será fechado. S adquire o som de X ou CH, sem o ponto terá o som original da letra S. Também não há plural. Faço essa opção reconhecendo a importância da oralidade na manutenção desta língua, mas acreditando também na importância da divulgação de sua forma escrita. Optei por misturar as grafias. Não há exotismo e nem arrogância na opção. Peço a mesma naturalidade que temos quanto ao uso de conceitos em alemão, francês, inglês, tão correntes em artigos acadêmicos.
} 
aos mais velhos. Lavei louça, varri o barracão, busquei meu lugar na fila do xirê (șire), a cerimônia pública em que dançamos em torno dos elementos centrais do terreiro, Ògún wá jó e màrìwón, cantando para Ogun, e sempre rodando no sentido anti horário, tudo recomeça. A cerimônia segue e cumpre seus movimentos. Se a Física já afirmou a impossibilidade de dois corpos ocuparem o mesmo lugar no espaço, talvez não se possa dizer o mesmo sobre dois lugares ocuparem o mesmo corpo. Xirê cantado completo, peguei a câmera fotográfica que sempre me aguarda silenciosa bem rente ao chão externo do barracão. Intervalo. Onde está Mene?

- Eu sei cantar a folha do Bàbá todinha. A minha folha eu também sei e a folha da minha mãe eu também sei. A sua folha, você sabe? É de cantar folha que eu gosto. Canta a sua.

Mene cantou as folhas que sabia e, respondendo ao que ela perguntou, cantei a minha. Jagun (2017) lembra que a folha (ewé) é um dos principais elementos da natureza utilizados em ritos do Candomblé, desde os iniciáticos aos fúnebres. Por isso o provérbio iorubá: Kò sí ewé, kòsí Òrị̀à (Sem folha não há Orixá). Já Verger (1995) resgata o indispensável:

Entre os iorubás, a preparação de remédios e trabalhos mágicos deve ser acompanhada de encantações ( $(f \hat{\jmath})$ com o nome das plantas, sem as quais esses remédios e trabalhos não agiriam. A transmissão oral do conhecimento é considerada o veículo do axé das palavras, que permanecem sem efeito em um texto escrito. Palavras para que possam agir, devem ser pronunciadas. Entre os iorubás, os $o f o ̣$ são frases curtas nas quais muito frequentemente o verbo que define a ação esperada, o verbo atuante, é uma das sílabas do nome da planta ou do ingrediente empregado. (VERGER, 1995, p. 36).

O elo com a folha (e com outros elementos) é a boca, que sopra, mastiga, cospe, e pronuncia palavra. Mas não se trata de palavra desabitada, já que conduz o ẹmí, o hálito sagrado na tradição oral. A palavra é ẹmí, é fala, verbo atuante.

Os terreiros, entre eles, os terreiros de candomblé, preservaram e ressignificaram modos de vida trazidos do Continente Africano durante a escravização. Conhecimentos sofisticados atravessaram o Atlântico e foram mantidos e reinventados nesses espaçostempos ${ }^{4}$. Uma das experiências protegidas é o complexo compartilhamento do conhecimento pela oralidade, muito embora o uso da escrita não seja visto como contraditório.

\footnotetext{
${ }^{3}$ Ògún vem dançar

${ }^{4}$ Alves explica que usa esses termos juntos para indicar que as pesquisas nos/dos/com os cotidianos pretende ir além do que vê como dicotomias e limites herdados das ciências modernas. Particularmente, em nossos textos, fazemos essa opção em apenas algumas expressões, este é um caso. Também optamos por dizer pesquisas com os cotidianos apenas.
} 
De geração após geração a cultura yorùbá é perpetuada nos candomblés, através dos itán (histórias), da invocação dos Deuses pelos orin (cânticos sagrados), das àdúra (súplicas e orações), dos òwe (provérbios), dos oríkì (louvações), dos $\boldsymbol{o} \boldsymbol{f} \boldsymbol{g}$, os encantamentos de elementos como as folhas, que Mene sabe cantar e encantar. No nosso terreiro, meu e de Mene, cada uma e cada um de nós, durante a iniciação, tem sua folha escolhida, em ritual específico e não público, por nosso próprio Orixá. Em todas as nossas demais obrigações (os ciclos periódicos que completam a iniciação), precisaremos cantá-la. Em alguns outros rituais da casa também. É por isso que Mene diz que sabe cantar a folha do Bàbá (nosso pai de santo), a folha da mãe dela (sua mãe carnal) e sua própria folha. É por isso que ela também me pergunta se eu sei a minha folha.

Nada nesse contínuo ensinaraprenderensinar do qual falávamos está apartado um do outro. Todos esses elementos se fabricam e se misturam, feito quando a gente coloca a farinha de milho branco (àgbàdo funfun) na panela para cozinhar e preparar o àkàsà, uma das mais importantes comidas rituais no candomblé. A água procura a farinha, a farinha procura a água e ambas vão sendo misturadas bem devagar até formar um creme que depois será cuidadosamente envolvido em uma folha de bananeira (șaf̣).

É então a palavrahálito que procura e une a boca ao ouvido das pessoas, dos elementos, dos Deuses, que empodera e distribuí. Ou enfraquece, já que a depender da palavra, esta também desarmoniza e destrói. O escritor malinês Amadou Hampâté Bâ (2010), ao recordar um poema ritual de seu país, explicita melhor: "A fala é divinamente exata, convém ser exato para com ela. A língua que falsifica a palavra vicia o sangue daquele que mente". (p.174).

Já posso dizer que os Estudos com Crianças de Terreiros, que desenvolvemos, nascem de duas grandes negações ${ }^{5}$, ou de dois grandes desprezos: o primeiro desprezo é herança hegemônica deixada pelo modo dominante com o qual a modernidade "via" os cotidianos, tidos como lugar de reprodução e saberes menores. Alves (2008) e em toda sua produção, vai afirmar os cotidianos como espaçostempos de criação, inteligência, imaginação, solidariedade, memória e invenção. Pesquisamos com os cotidianos dos terreiros, espaçostempos de complexos conhecimentos.

O segundo grande desprezo é aquele que marca as concepções e abordagens sociológicas negando a criança como sujeito de conhecimento e participação social, portanto silenciando-as. Tanto alguns estudos da antropologia, como os novos Estudos Sociais da Infância

\footnotetext{
${ }^{5}$ Há ainda duas outras negações contidas nessas que apontamos. As crianças de terreiros continuam pouco visíveis como sujeitos tanto para os Estudos da Infância como para os estudos das relações étnico-raciais.
} 
foram áreas de conhecimentos que buscaram (e já conseguiram, em certa medida), diminuir uma determinada visão subalternizante das crianças na sociedade e na produção de conhecimentos. Para Ferreira (2010), na originalidade dessa nova Sociologia da Infância confluem a "interdependência conceitual e prática entre infância e crianças e a inversão da perspectiva de análise sobre o conhecimento da realidade contemporânea a partir da infância e das interpretações e questionamentos que as próprias crianças elaboram acerca das suas circunstâncias de vida e do mundo social". (pgs 154, 155).

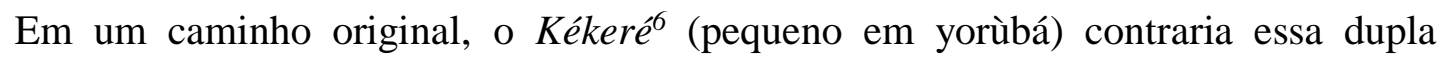
negação para inverter e afirmar que, justamente aquilo que é considerado menor (os cotidianos), e quem é considerado menor ainda (as crianças), são fundamentos vitais para compreender a sociedade em que vivemos, bem como desestabilizar suas lógicas coloniais profundas. A proposta desse artigo é apresentar algumas notas de nosso percurso e dos fundamentos que nos animam: ẹmí kékeré, ara kékeré, imo kékeré.

Se tive sorte, com a fala de Mene, espero ter compartilhado o primeiro fundamento que nos despertou para as pesquisas que praticamos. Fundamento é uma palavra bastante comum nos terreiros quando se quer dizer que algo está envolvido por profundos e complexos conhecimentos, bem como seus modos de fazer. Se o ẹmí é a palavrapoder dos candomblecistas, interessa-nos o ẹmí kékeré, o ẹ̀mi omọdé, a palavra-sopro miúda, a palavra soprada das crianças de terreiros. Elas mesmas verbos atuantes. É por isso que nos textos que escrevo (e que tento praticar com todo meu grupo de pesquisa) as crianças são sempre as primeiras a falar. Se elas falam primeiro (e continuarão falando aqui) é porque as ouvimos primeiro. Em yorùbá, gbó é ouvir. Já a palavra ợà (pronuncia-se onan) significa caminho e também é uma qualidade de Exu (senhor dos caminhos). A esse primeiro caminho praticado, caminho vivenciado, chamo de gbọ́kékeré, gbọ omọé. Ouvir o miúdo, ouvir a criança.

Depois disso, antes de seguir, convém cantar uma folha, ao menos um trecho de uma cantiga que exalta o poder das ewé e suplica, segundo Pessoa de Barros (2011) para que seu axé se espalhe e beneficie o processo em curso. O que também desejamos aqui.

\section{E omodẹ kékeré ènyín}

Ènyín nsire idi kan là

\footnotetext{
${ }^{6}$ Grupo de Pesquisa do Proped Uerj 


\section{E t'awa fifun nyin l'asé}

Ènyín nsire idi kan là

Omodẹ kékeré ènyín

Ènyín nsire idi kókó

(Criança pequena, vocês estão fazendo festa grande, por isso que nós lhe damos axé. Vocês estão fazendo festa grande. Criança pequena, vocês estão fazendo festa de semente)

A cantiga talvez evidencie a sofisticação e complexidade da relação criança-terreiro. Respeitadas como sujeitos, atores sociais ativos e dinâmicos, as crianças, aqui, não são incompletos receptáculos da vida adulta, aprisionadas e enfraquecidas num sempre estágio de vir a ser. São vistas como o futuro do candomblé, continuação das casas e da tradição (festa de semente), mas são também os sujeitos atuantes que fazem a festa hoje (vocês estão fazendo festa grande).

\section{2 - "Eu sou mais velho do que minha mãe" Ara Kékeré, Ara Omọdé - corpo miúdo, corpo da criança}

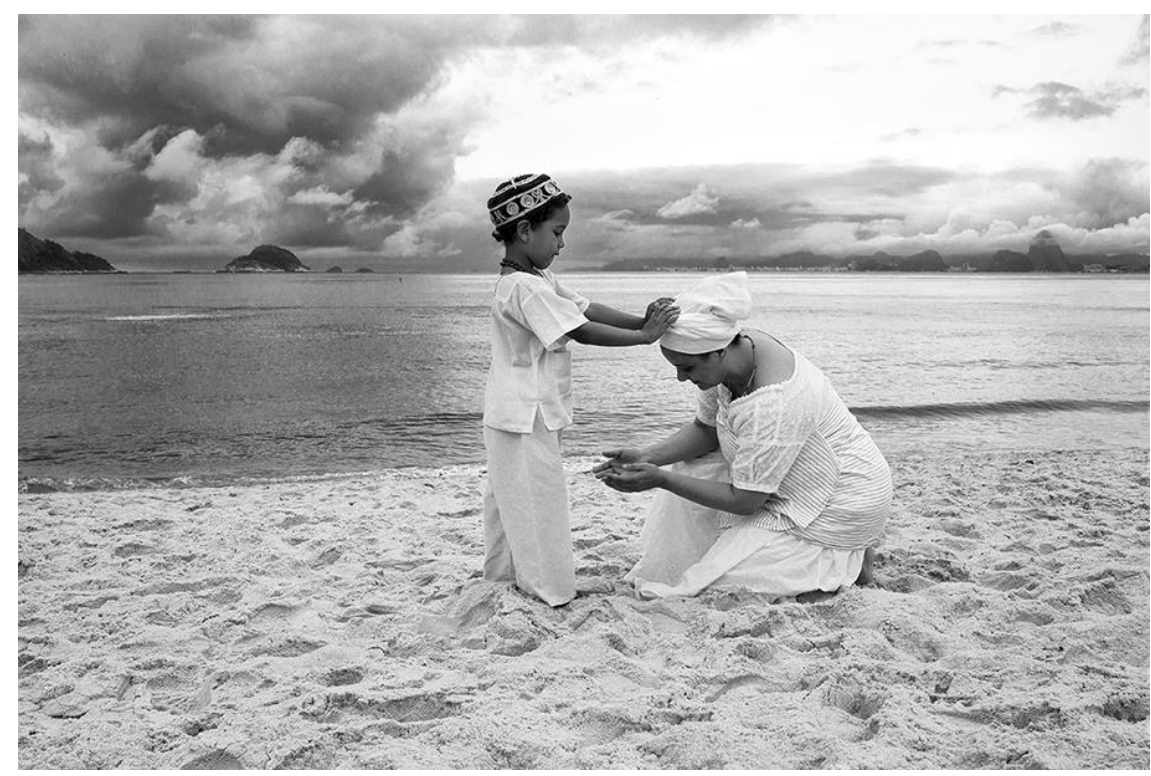

A foto acima mostra Anísio Moreira Costa, de 4 anos, abençoando sua mãe, Clarisse Mantuano, de 40, que se abaixa, se curva e toma a bença ao seu mais velho. O menino é mais velho? 
"Eu sou mais velho do que minha mãe porque sou ogan. Eu sou o mais velho de muita gente que é grande. Sou mais velho que ela, é simples", disse Anísio Moreira Costa, na tarde de 12 de janeiro de 2018, enquanto andávamos pela praia de Itaipú, em Niterói. O menino de 4 anos, não só é mais velho, como é avô de sua mãe, Clarisse Mantuano, desde o dia 4 de maio de 2013, quando, aos dois meses de idade, foi suspenso ogan pela Yemanjá da avó carnal e paterna, Beata de Yemanjá, Iyalorixá, do Ilé Omiojúàró (Ilê Omiojuarô - Casa das Águas dos Olhos do Caçador), em Miguel Couto, na Baixada Fluminense. Ser suspenso significa ser apontado, indicado, escolhido pelo Orixá para um determinado cargo que deverá ser confirmado em ritual. Aos dois meses, ao ser suspenso ogan, Anísio é neto, mas também se tornou pai da própria avó paterna (Mãe Beata e seu filho Aderbal, pai de Anísio eram irmãos de santo) e avô de sua mãe, já que Clarisse, sua mãe biológica, era filha de santo de Beata.

Seguindo recomendação não da avó, mas de Yemanjá, orixá da avó Beata, a confirmação de Aníso não tardou e, no 27 de junho de 2015, o menino foi confirmado e apresentado publicamente como ogan alabê $\hat{e}^{7}$. Os terreiros, com suas sofisticadas relações de parentesco, desestabilizam o que compreendemos como família e idade. Quem é mais velho? Quem é mais mais novo? Sugiro o seguinte: voltemos à foto, vejamos juntos as mãos de Anísio sobre a cabeça de sua mãe e leiamos tudo outra vez mais devagar. Será necessário para seguirmos.

Começamos falando da palavrahálito que carrega saber e força. Risério (1996) lembra que essa palavra tem que ser dita por uma pessoa a outra e é rigorosamente interpessoal. "Sue emissão é acompanhada por movimentos corporais. A palavra tem que ser proferida com o corpo, a respiração, o hálito, a saliva, a temperatura". (p. 64). O ensinamento remete ao que Bâ diz sobre uma outra tradição africana, a bambara do $\mathrm{Komo}^{8}$ :

Assinalemos, entretanto, que, os termos falar e escutar referem-se a realidades muito mais amplas do que as que normalmente lhes atribuímos. De fato, diz-se que quando Maa Ngala fala, pode-se ver, ouvir, cheirar, saborear e tocar sua fala. Trata-se de uma percepção total, de um conhecimento no qual o ser se envolve na totalidade. (BÂA, 2010, p. $168)^{9}$.

\footnotetext{
${ }^{7}$ Ogan é tocador dos atabaques no Candomblé. É um cargo masculino (adultos ou crianças) que não entram em transe. Alágbè (alabê) também é cargo masculino, conferido a um ogan que passa a ser responsável por, tanto tocar os como cantar os cânticos sagrados.

${ }^{8}$ Uma das grandes escolas de iniciação do Mande (Mali) para quem o Ser Supremo é Maa Ngala.

${ }^{9}$ O Continete Africano possui mais de 50 países, milhares de religiões e línguas, portanto, distintos modos de vida. Mas encontramos semelhanças, como as narradas por Bâ e as incluimos em nossos diálogos.
} 
Essa concepção de totalidade também está presente entre os yorùbá. Por isso não podemos conversar sobre ara (corpo) e pensar sobre essa fotografia que trouxemos, sem falar sobre senioridade e ancestralidade. Mas, antes, os yorùbá ${ }^{10} \ldots$

Jagun (2015), explica que o chamado povo yorùbá está atualmente em três países da África: Nigéria, Benin e Togo. Entre nós, diz o pesquisador, os yorùbá começaram a chegar na segunda metade do século XIX trazidos escravizados. Yorùbá é povo e língua, sendo uma das centenas de línguas faladas, ainda hoje, nesses países. No Brasil, seu último refúgio, afirma Beniste (2006), foi (e ainda é, sabemos) as comunidades de candomblé, chamadas roças, casas, ilè onde tem sido mantida através de cânticos, rezas e expressões diversas.

Os yorùbás, segundo Sàlámì (2011), consideram a pessoa constituída dos seguintes princípios vitais: $\operatorname{ara}^{11}$ (corpo físico), òjìji (sombra), ọkàn (coração), ẹmí (hálito) e orí (cabeça). Trata-se da compreensão do corpo como um todo que não descarta o entendimento filosófico de cada parte desse corpo.

A escravização foi um projeto de aniquilamento de povos negros e suas culturas implementado pela lógica colonial que uniu intenções mercantis e intenções de submissão étnica. Só para as Américas, o comércio atlântico de escravos trouxe cerca de doze milhões de pessoas escravizadas. As consequências foram e continuam sendo terríveis, basta ver as dimensões das desigualdades na sociedade brasileira que atigem, sobretudo, às populações negras.

Contudo, como assinalam Simas \& Rufino (2018), os corpos atravessados nas encruzilhadas transatlânticas transgrediram a lógica colonial:

O corpo objetificado, desencantado, como pretendido pelo colonialismo, dribla e golpeia a lógica dominante. A partir de suas potências, sabedorias encarnadas nos esquemas corporais, recriam-se mundos e encantam-se as mais variadas formas de vida. Essa dinâmica só é possível por meio do corpo, suporte de saber e memória, que nos ritos reinventa a vida e ressalta suas potências. (Simas \& Rufino, 2018, p. 49).

Pessoa de Barros (1989) já havia mencionado a construção social da pessoa nos terreiros de candomblés desenvolvida, diz ele, a partir da iniciação e vivência cotidiana nesses espaços onde o sistema de crenças privilegia o corpo humano. Para este autor, a percepção do corpo como conjunto de representações que ultrapassam as características biológicas, também pode ser explicada porque, no candomblé, o corpo humano é veículo da comunicação com os deuses ou forças da natureza.

${ }^{10}$ Se a opção for a palavra escrita em português, aí caberá o plural yorubás.

${ }^{11}$ Com esse autor encontrei a palavra grafada assim. 
Já no finalzinho de "Educação nos terreiros", Caputo (2012) diz de seu desejo de voltar a Bara, cuja palavra reúne Oba (rei) e Ara (corpo), um nome atribuído a Eșú Bara ${ }^{12}$, o movimento do corpo e solicitou aos leitores que procurassem as narrativas dos corpos nas fotos espalhadas pelo livro. Os corpos são centro de inscrições, símbolo das relações (repetindo Pessoa de Barros) e são, afirmo, ara-ìtán (mais atrás expliquei que itán são narrativas iorubanas repetidas e ressignificadas cotidianamente nos terreiros). É para o corpo-ìtán, o corpo narrador que a pessoa deve olhar para entender o que acontece no terreiro. Seja para entender o ato de um Orixá, por exemplo, seja para se aproximar dos saberes e lógicas cotidianas de uma casa. Já podemos apresentar o segundo fundamento que desperta nossas pesquisas. Todo ara, todo corpo nos interessa nos terreiros. Mas é o ara kékeré, o ara omọdé, o corpo miúdo, o corpo das crianças de terreiros que nos interessa detidamente. A esse segundo caminho praticado, caminho vivenciado, chamo de ojú kékeré, ojú omọé. Olhar o miúdo, olhar a criança.

Na fotografia trazida, vimos que Anísio inverte a lógica adultocêntrica de nossa sociedade. Nessa lógica, que já acostumou nossos olhares, o corpo miúdo deveria estar curvado para o corpo adulto se a situação pedisse alguma reverência. A inversão provocada pelos saberes de terreiros é mais profunda porque nos ensina, em vertigem, que ele, Anísio menino é avô da mãe. Evidente está que as crianças de terreiros são sujeitos dinâmicos de conhecimentos e ações. Assim, nos pareamos com os estudos da infância que, na ênfase de Sarmento (2008) percebem as crianças como atores sociais. Defendemos, também com Sarmento (2005) que a sociologia da infância interroga a sociedade a partir do ponto de vista dessas pesquisas. São estudos que ampliam os conhecimentos não apenas sobre a infância, mas da sociedade como um todo.

Anísio Moreira, de 4 anos, é mais velho do que sua mãe, Clarisse Mantuano, de 40. A idade iniciática, tanto como o cargo recebido, desestabiliza a condição etária no modo como a conhecemos. A idade iniciática é mais importante que a idade civil.

Esse fundamento, a idade iniciática, proporciona uma vivência paradoxal do conceito de geração. Do lado de fora do terreiro, na relação com pessoas alheias ao candomblé, Anísio tem "apenas" 4 anos. Dentro do terreiro e na relação com pessoas de terreiro, ainda que fora dos terreiros, ele também tem 4 anos, é protegido e cuidado. Respeita e obedece aos pais e aos mais velhos civilmente sem que isso o subalternize, mesmo que não tivesse um cargo.

\footnotetext{
12 Já em Jagun (2017), lemos que provavelmente Bara vem de Ba (v. esconder) + ara (corpo). Ou Ba (prep. com, em companhia de), significando uma energia própria do ser humano. (P. 965).
} 
Digo isso para não passar a falsa impressão de que só as crianças iniciadas e só as crianças com cargos de ogan, como Anísio, por exemplo, são respeitadas nos terreiros. Toda criança é respeitada e cuidada não só por sua família carnal, mas por toda comunidade, inclusive porque que a família de santo amplia os laços de parentesco. Talvez um provérbio iorubá nos ajude a compreender melhor a visão de um espaço em que as crianças não são percebidas como inferiores e os adultos como superiores: a mão de uma criança não consegue alcançar uma preteleira, a mão de um adulto não entra em uma cabaça.

Anísio, além disso, também pertence a uma geração mais velha. Ou seja, os terreiros não congelam a infância subalternizada aos adultos e Anísio sabe disso. "Eu sou mais velho do que minha mãe porque sou ogan. Eu sou o mais velho de muita gente que é grande. Sou mais velho que ela, é simples", lembremos de sua fala. Sarmento $(2005,2008)$ já solicitou atenção para as singularidades e diferenças (culturais inclusive) que atravessam essa discussão. Nós ouvimos e, de dentro dos Estudos com as Crianças de Terreiros, também solicitamos atenção para as singularidades com as quais caminhamos em nossas pesquisas.

\section{3 - "E quando ela virava o céu parecia que baixava"}

\section{İmọ Kékeré, İmọ Omọdé - Conhecimento miúdo, conhecimento da criança}

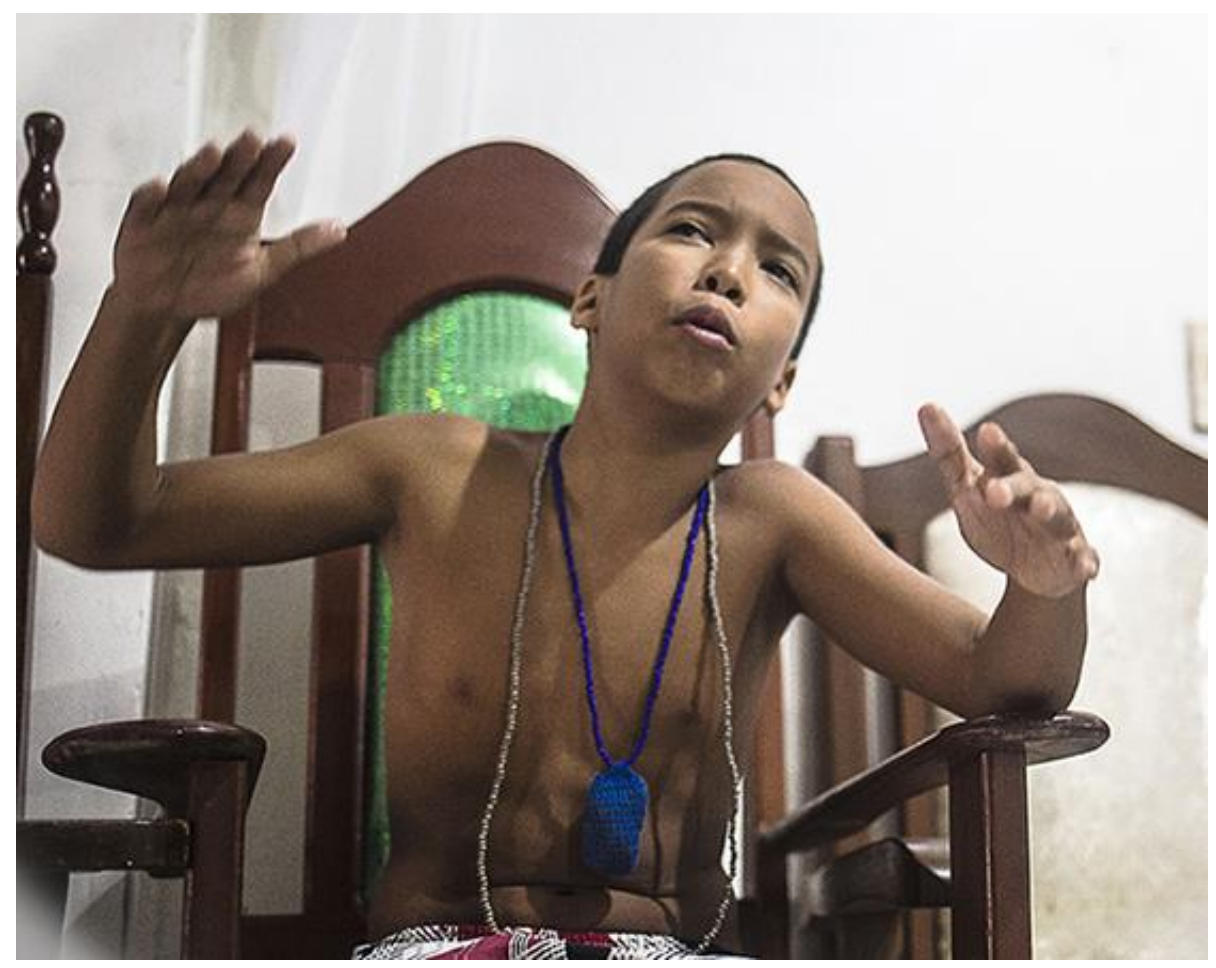


- A gente começou cantando para Exu, aqui, despachou. E a gente foi pra Salinas ${ }^{13}$. A gente fez as cestas de frutas e levamos para a praia para entregar o presente de Yemonjá. A minha tia foi e a gente precisou cantar para Nanã. Quando a gente cantou ela virou pra Nanã e quanto ela virou, todo mundo virou. Só ficou a mamãe. Foi muito, muito lindo. Quando ela virou o céu parecia que baixava e as estrelas ficaram mais próximas.

A narrativa é de Antônio de Nazaré Oguntolá Azevedo Santos, 11 anos, ao contar o que sentiu quando viu, naquele presente para Yemanjá, sua tia-avó, dona Maria Aparecida, virar de Nanã, uma das divindades mais antigas nos candomblés brasileiros. A conversa com Oguntolá aconteceu no dia 3 de junho de 2017, no Ilè Àsé Iyá Ogunté, em Ananindeua, Belém, terreiro onde o menino é Bàbá Egbẹ́(Pai da Comunidade). Antes de falar do cargo do menino, precisamos falar do nome do menino. Oguntolá, que integra seu nome civil e registrado, é parte do nome recebido no ikọ́mojàde e parte do orúkọ (o nome ritual de uma pessoa no candomblé).

\subsection{1 - Rituais do nome: ik ọ́mojàde e orúko}

- Me iniciei para Yemojá com 7 anos, pelas mãos do mesmo Pai de Santo de minha mãe carnal, pai de Walmir de Odé. Antes disso fiz meu ikọ́mojàde, meu batismo. Em em 2014, fiz minha obrigação de 1 ano, em 2017 dei meus três anos e, para minha surpresa, meu pai, que trabalha lá para Marabá conseguiu vir para minha obrigação e terminou pagando também seus 7 anos que foi lindo! Quem viu viu! Meu pai deu um boi! Todos os Orixás viraram. Quem perdeu, perdeu!

O ikọ́mojàde, como disse Antônio, é uma cerimônia de dar nome ao recém nascido (omọ titun). Mãe Rita de Azevedo, Iyálorixá ${ }^{14}$ da casa, e mãe carnal de Antônio, conta que o ritual de seu filho aconteceu sete dias após o seu nascimento ${ }^{15}$, no dia 10 de dezembro de 2005 . A placenta e seu cordão umbilical foram enterrados em um igbá (cabaça) aos pés da aroeira, árvore mais alta e frondosa do terreiro, que fica na porta de entrada da casa e servirá de guardiã ao fundamento que lhe foi confiado na terra ao redor de suas raízes. Esse igbá, diz Mãe Rita, foi cuidadosamente preparado por Pai Walmir da Luz Fernandes (seu Pai de Santo), para receber os órgãos e os fundamentos, tanto físicos como energéticos. Foi amorosamente pintado com símbolos rituais em sua parte externa, que é branca. Nesse cerimônia, Antônio recebeu seu primeiro nome ritual: Oguntolá.

\footnotetext{
${ }^{13}$ Salinópolis, comumente chamado de Salinas, município no Nordeste do Para, já na ponta do litoral Atlântico do estado.

${ }^{14}$ Maior liderança da casa de Candomblé, Mãe de Santo.

${ }^{15}$ No processo descrito por Epega (2005), encontramos o inverso: 9 dias (sendo menino), 7 dias (sendo menina) e 8 dias (sendo gêmeos). Vale consultar seu texto sobre o assunto em: MOURA (Org), "Sọmàvo, O amanhã nunca termina - novos escritos sobre a religião dos voduns e orixás. Empório, 2005.
} 
Sete anos depois, na sua iniciação (como é cargo dizemos confirmação), portanto, quando se confirmou como Bàbá Ẹgbẹ́, Mãe Rita explica que seu filho recebeu o onde, um artefato, tido como amuleto contendo, além de outros fundamentos, pequenos restos de sua placenta e cordão umbilical pedidos de volta à aroeira. O colar ritual fica com o menino que o usa sempre que quiser. Peço que voltem à foto anterior. Esse artefato, é o cordão azul no pescoço de Oguntolá ${ }^{16}$.

Nessa mesma obrigação, Antônio recebeu a versão integral de seu orúko, seu nome ritual no candomblé. Em geral, o orúkọ completo não é conhecido por todos. Atualmente, ele é chamado também pelo seu cargo de Bàbá Egbé, mas é como Oguntolá (trecho menor que já havia sido dado em seu ikọ́mojàde) que Antônio continua a ser conhecido na comunidade.

Hoje, nem todo terreiro mantém essa tradição e, mesmo nas casas que o realizam há variações de terreiro para terreiro (como todo ritual). No Brasil, em geral, as placentas são jogadas no lixo ou incineradas pelos hospitais e nem toda mãe consegue decidir sobre o destino desse órgão ${ }^{17}$.

Para a mitologia yorùbá Jagun (2017) afirma que a placenta (olóbi) é impregnada pelas últimas lembranças do espírito que escolhera seu destino, antes de nascer. Enterrar a placenta na terra, diz o pesquisador, é solidificar as escolhas feitas antes de nascer, para que se cumpram durante sua permanência no mundo. Já o orúkọ proporciona um renascimento mítico e é tão ligado ao orixá individual que a própria divindade o pronuncia, em ritual.

\subsection{2 - "Eu toco porque sou Bàbá Egbẹ"}

\footnotetext{
${ }^{16}$ Partes da discussão que compartilho nesse texto foi realizada com meu grupo de pesquisa, o Kékeré. Especificamente sobre esse artigo, agradeço a interlocução cotidiana com: Adailton Moreira Babalorixá do Ileomiojuarô e ao doutorando Ataíde Junior, integrante do Ilè Àsé Iyá Ogunté.

${ }^{17}$ A OMS, em seu item 8, diz que as instituições de saúde devem preservar o direito das mulheres decidirem, inclusive, sobre o destino da placenta.
} 


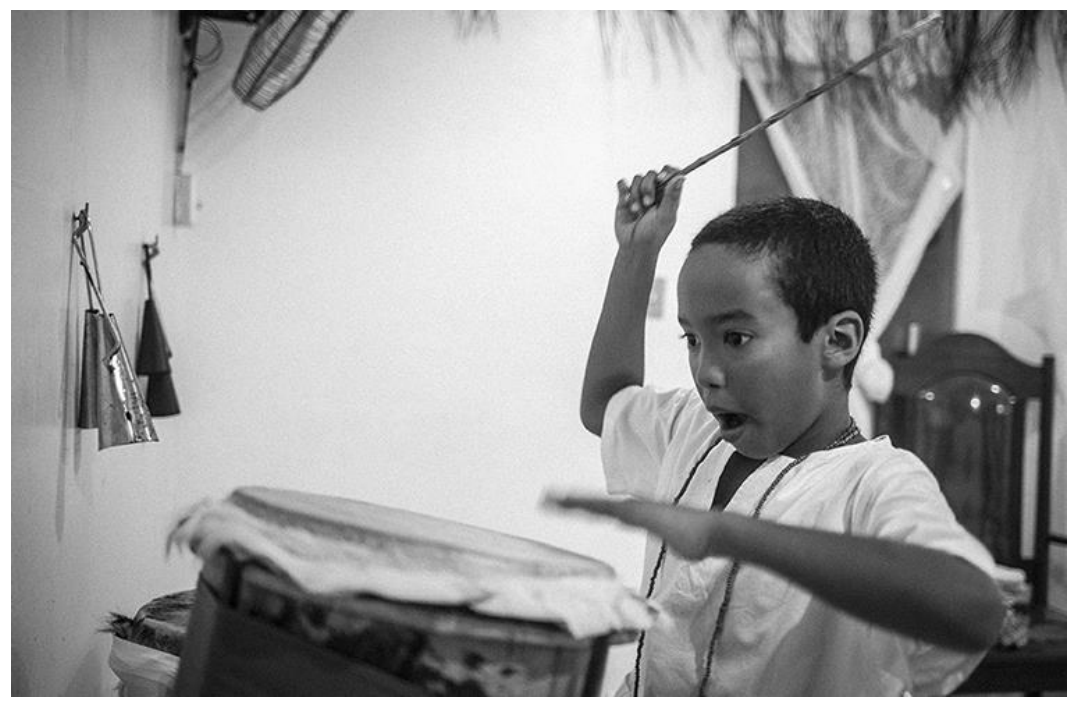

- Bàbá Egbée é o pai da comunidade, é um cargo de muita responsabilidade. E Yemojá já disse que sou o herdeiro da casa. O herdeiro assume quando a Mãe de Santo ou Pai de Santo morrem. Mas você não precisa esperar isso acontecer para assumir seu lugar de herdeiro. Eu já dou bọí (oferenda à cabeça), mas para iniciar alguém aí minha irmã é que está sendo preparada, ela vai poder iniciar.

Oguntolá sabe que não necessariamente o Bàbá Eggbẹ herda a direção do terreiro, mas enfatiza que o Orixá da casa já decidiu que ele será o sucessor de sua mãe. Sabe também que, como ogan, não é um rodante, ou seja, não vira no santo. Sabe que isso não o impede de herdar a casa e ser responsável pela casa. Mas sabe, contudo que, não sendo rodante, não pode iniciar ninguém, ainda que possa realizar outros ritos importantes como o borí, por exemplo. É por isso que Oguntolá vai dirigir a casa um dia, mas é a irmã quem está sendo preparada para desempenhar a função de iniciar novos filhos e filhas.

Como ògán alágbè (o mesmo posto dos meninos Anísio e Odin) ele toca e canta, para que os rituais possam acontecer, atribuições que também não são incompatíveis com o cargo de Bàbá Eggbẹ́ da casa. Oguntolá foi assumindo essa função inicialmente porque seu terreiro não tinha ogans suficientes, mas sobre isso ele tem a seguinte opinião: "Mesmo quando tiver alágbè suficiente, eu ainda vou poder tocar sim, se eu quiser. Eu não sou obrigado a tocar só quando não tiver alágbè. Eu toco porque sou Bàbá Egbẹ́ e um Bàbá Eggbé precisa saber fazer tudo", afirma. Ainda sobre tocar e cantar, o menino diz que tocar é mais difícil e elege o toque chamado egó, como o mais complicado. Egó, explica Oguntolá, pode ser tocado para alguns orixás, sendo mais comumente tocado para Iansã. Alguns toques exigem que o ogan combine a mão com a àtòri, 
uma vareta de madeira para a percussão também chamada de agdavi (akidavi). "Aprendo olhando e repetindo, mas às vezes um mais velho vem e me ensina", diz Oguntolá. Os atabaques precisam receber os toques impecavelmente para que o Orixá venha e o o ritual seja feito como deve ser. Não é raro ver mães ou pais de santo interromperem um ogan, seja adulto ou criança, que não esteja realizando o toque de maneira correta. Às vezes é o Orixá que interfere. No caso dos cultos de Egúngún (culto aos mortos), já vi o próprio Egún (o espírito do morto) fazer isso.

Me interesso, e nosso grupo de pesquisa também se interessa, por todos os conhecimentos que cotidianamente enfrentam a racionalidade hegemônica da colonialidade. Contudo, enfatizo nesse momento, nosso terceiro fundamento que nos orienta nas pesquisas: o ìmọ kékeré, o conhecimento miúdo, o conhecimento das criança de terreiros. O ìm ọ kékeré nos leva ao terceiro caminho praticado, caminho vivenciado que chamo de Kệọ́ékeré, Kệkó omọdé. Aprender com o miúdo, aprender com a criança.

2 - "A gente olha para a boca da mais velha e canta"

Ojú omọé: os olhos das crianças, olhar com as crianças 


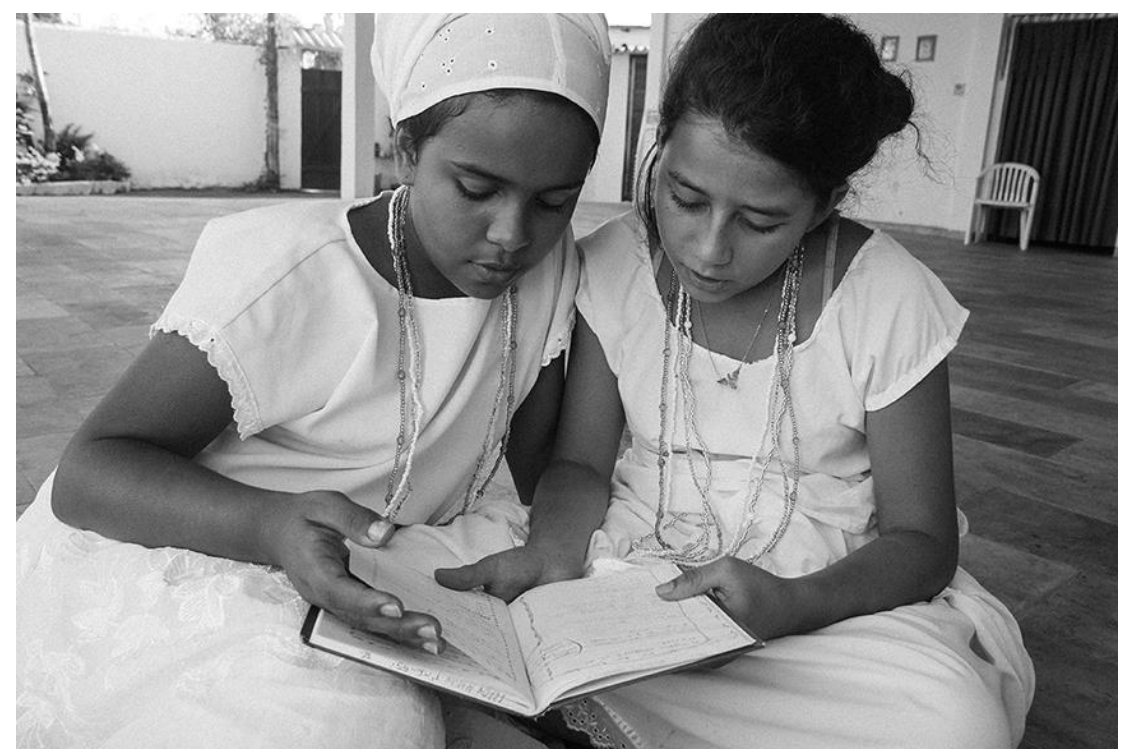

- A gente aprende olhando. Olha, olha outra vez, repete o pé, a mão, a dança. Vai repetindo com o corpo até o corpo ir certo. Repete a cantiga até cantar certo. A gente aprende um com o outro, com os mais velhos. A gente também pode anotar nos cadernos. Eu gosto de escrever principalmente as cantigas. Me ajuda lembrar quando eu escrevo e com os cadernos aqui a gente pode olhar nas horas vagas. (Mariah Moreira, 12 anos).

Existem muitos modos de aprenderensinar em terreiros. Olhar o mais velho, a mais velha (em idade iniciática) é a maneira mais relatada pelas crianças. Mariah Moreira e Letícia Mattos, são ekedes (èkéjì) no Ilè Aṣé Omi Laare İyá Sagbá (já mencionado). As ekedes, são cargos femininos e, assim como os ogan, não incorporam Orixás. Se os ogans são considerados pais, as ekedes são consideradas mães. Possuem inúmeras funções, uma delas é cuidar dos Orixás quando estes estão no àiyé (aqui na terra).

"Foi uma honra receber esse cargo e saber que fomos escolhidas pelo ancestral para cuidar deles. Significa que ele confia em nós e acha que somos capazes de cuidar deles, das coisas deles, dos filhos deles", diz Letícia Mattos, 12 anos. Para ela, a autorização dada pelo Pai de Santo, Daniel de Yemanjá, para o uso de cadernos em seu terreiro é positiva. "A gente olha para a boca da mais velha e canta. A gente olha pro jeito como a mais velha joga o ombro e faz. A gente olha para o gesto da mais velha e repete. A mais velha sabe. E sim escrever a cantiga facilita", concorda Letícia.

Nem todo terreiro autoriza o uso de cadernos. Em muitos, a oralidade e observação, como vimos, são modos prioritários de compartilhar conhecimentos de geração em geração. O que não significa dizer que a escrita inexista nos terreiros. Castillo (2010) identificou três tipos diferentes de cadernos em suas pesquisas: o registro de terreiro, com informações administrativas; o caderno 
de iâ̂, preparado, diz a pesquisadora, em alguns terreiros, pelas pessoas mais velhas para as mais novas, contendo ensinamentos básicos e entregue após a iniciação e o caderno de fundamento, parecido com o caderno de iaô só que, por conter mais segredos, deve ser muito bem guardado e não revelado. No terreiro de Mariah e Letícia (que também é o meu) existem ao menos dois tipos de cadernos. Um, que se assemelha tanto ao caderno de iaô como ao caderno de fundamento descritos por Castillo. Quando nos iniciamos, ganhamos do Pai de Santo um caderno que nos acompanha a partir e durante a iniciação. É mesmo um diário no qual escrevemos cotidianamente os ensinamentos do recolhimento. Ali também poderemos anotar, após a iniciação, outros processos que acharmos por bem anotar. Esse caderno é íntimo, secreto e não pode ser revelado. Um segundo caderno vai conter ensinamentos, cantigas, aprendizados, mas todos de carater não secreto. É esse segundo tipo de caderno, o caderno de Mariah, que está nas mãos das ekedes na fotografia que trouxe para nossa conversa.

Volto ao que as meninas disseram para lembrar que Santos (1993), também já enfatizou que a transmissão do conhecimento nos terreiros se dá através de complexa trama simbólica em que o oral constitui um dos elementos, o princípio básico da comunicação constituído pela relação interpessoal. Santos afirma que, ao menos duas pessoas são indispensáveis para que haja transmissão de conhecimento efetuando-se: "através de gestos, palavras proferidas acompanhadas de movimento corporal, com a respiração e o hálito que dão a vida à matéria inerte e atingem os planos mais profundos da personalidade". (Santos, 1993, p. 50).

Em suas palestras, o Babalorixá e escritor, Márcio de Jagun, lembra que o idioma yorùbá é tonal e, conforme a entonação o significado da palavra muda. Diz também que os vocábulos yorùbás, sobretudo os verbos, são polissêmicos, deslizando significados a depender do contexto da frase. Existe uma pequena palavra em yorùbá que, entre outras coisas (a depender do contexto em que é utilizada) significa tanto ensinar como aprender. Trata-se do verbo $K \hat{o}^{18}$. Ensinaraprender em terreiros reúne o compartilhamento do conhecimento (ìmọ), dos gestos e movimento corporal (ara), da fala, respiração e hálito (ẹ̀mí). Lembremos do que disse há pouco a equede Letícia, de 12 anos: "A gente olha para a boca da mais velha e canta. A gente olha pro jeito como a mais velha joga o ombro e faz. A gente olha para o gesto da mais velha e repete. A mais velha sabe. "

Um bom lugar para se reparar essa tríade de fundamentos é o șiré (xirê). Na maioria das casas em que pesquiso, o xiré é dançado em sentido anti-horário, em torno dos elementos centrais

\footnotetext{
${ }^{18}$ Também pode ser, como já dissemos Kệoó. Beniste (2009) traz em verberte Kọ́: ensinar, aprender, educar. (p. 469).
} 
do terreiro. A explicação que já me foi dada é que o ato inverte a lógica do tempo, sendo a oportunidade de voltar a um tempo ancestral. Na roda do xirê os mais velhos seguem à frente. Lembrando que uma criança pode estar na frente de um adulto sempre que sua idade iniciática for maior. É nessa roda que, como disse Letícia, podemos buscar a boca da mais velha, o gesto da mais velha, no círculo que se forma e gira. O sentido da busca é tanto encontrar o ancestral mítico (no retorno do tempo), como o mais velho, a mais velha coetâneos, sendo adultos ou crianças.

A simbologia com o círculo também nos remete a Oxumarê, orixá que é serpente-arco-íris, como diz Verger (2002). Mobilidade e atividade, Oxumarê é senhor de tudo o que é alongado. De acordo com Verger, o cordão umbilical está sob controle desse orixá (e já descrevemos o ritual do nome que envolve o órgão aqui).

Ele é símbolo da continuidade e da permanência e, algumas vezes, é representado por uma serpente que se enrosca e morde a própria cauda. Enrola-se em volta da terra para impedí-la de se desagregar. Se perdesse as forças, isso seria o fim do mundo, (VERGER, 2002, p. 206).

A figura da serpente, e sua representação de Oxumarê, é mais conhecida nos terreiros que frequentamos. É com ela então que representaremos os fundamentos de nosso ọnà (caminho) em pesquisa. Lembramos que Verger, ao narrar o poder de Oxumarê, avisa que se a serpente "perdesse as forças, isso seria o fim do mundo" e sugere não negligenciarmos as suas oferendas.

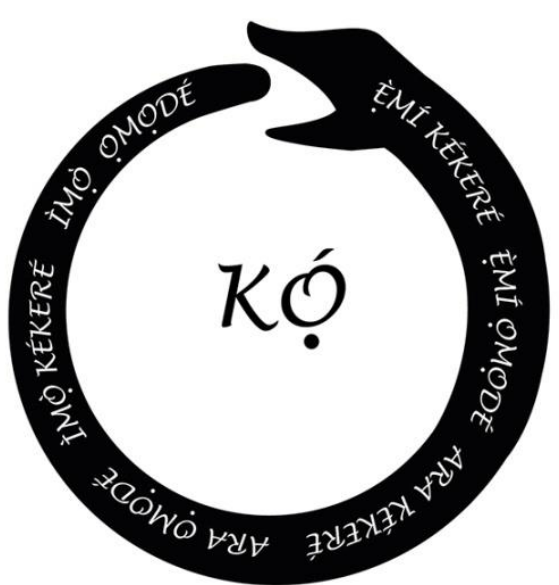

\section{3 - Caminhos praticados, caminhos vivenciados}

Cotidianos, etnografia, multirreferencialidade, abeiramento 
Nos limites desse artigo, trouxemos algumas reflexões sobre nossos Estudos com Crianças de Terreiros e tivemos a intenção prioritária de partilhar alguns fundamentos. Achamos que era nossa responsabilidade fazer isso. Esperamos agora poder dividir indícios dos movimentos de pesquisas que nos inspiram sem ter a pretensão de aprofundar qualquer um deles.

Nós, do Kékeré, não somos antropólogos (alguns colaboradores são), mas concordamos com Ferreira, quando lembra James \&Prout (1990), em seu argumento de que a etnografia é modo profícuo nas pesquisas com crianças. Contudo, guardamos a prudência sugerida pela antropóloga Mariza Peirano, para quem, etnografia não é método já que, a boa etnografia, diz a pesquisadora, não esquarteja empiria e teoria.

Se o trabalho de campo se faz pelo diálogo vivido que, depois é revelado por meio da escrita, é necessário ultrapassar o senso comum ocidental que acredita que a linguagem é basicamente referencial. Que ela apenas "diz" e "descreve" com base na relação entre uma palavra e uma coisa. Ao contrário, palavras fazem coisas, trazem consequências, realizam tarefas, comunicam. E palavras não são o único meio de comunicação: silêncios comunicam. Da mesma maneira os outros sentidos (olfato, visão, espaço, tato, têm implicações que é necessário avaliar e analisar. (PEIRANO, 2014, p. 386).

As sugestões de Peirano encontram as de Alves (2008) no primeiro dos seis movimentos que esta última elenca necessários às pesquisas com os cotidianos: "É preciso executar um mergulho com todos os sentidos no que desejo estudar". (p. 17).

Se Peirano (2014) afirma que todo antropólogo, ao estar no campo, reinventa a antropologia, gostamos de pensar que o inverso também é possível. A etnografia reinventa o pesquisador. Foi o tempo passado nos candomblés que nos conduziu aos cadernos de campo, às gravações de conversas e entrevistas, aos antropólogos e suas formas de fazerpensar, às fotografias, aos fotógrafos e suas formas de escrever com luzes e sombras, aos mergulhos por grandes, imensos períodos passados em terreiros no Rio, Ilhéus, Goiás, Cerá, Recife, Itaparica, Florianópolis, Belém, Maranhão e em tantos outros lugares onde crianças dançam ao ritmo dos atabaques ao lado de Deuses africanos e seus parentes, vivos e mortos.

Nossas pesquisas entendem os terreiros como espaços de preservação, reinvenção e circulação de sofisticados conhecimentos trazidos por diversos grupos africanos sequestrados e escravizados. Justamente os conhecimentos cotidianos que nos interessam. Nilda Alves não pesquisou terreiros de Candomblé, mas entende o mundo como redes educativas.

Em seu viver cotidiano, os seres humanos se articulam em múltiplas redes educativas que formam e nas quais se formam - como cidadãos, trabalhadores, habitantes de espaçostempos diversos, criadores de conhecimentos e significações e de expressões artísticas, membros de coletivos vários (famílias, religiões, expressões nas mídias), etc etc. (ALVES, 2012, p. 1). 
Nessa potente rede de criações cotidianas temos, como vimos, por escolha fundamental de pesquisa, conviver com crianças de terreiros, no que chamávamos de relações horizontais entre crianças. Corsaro (2011), contudo, já trazia um conceito mais pertinente, ainda que também não pesquisasse crianças em terreiros. É portanto, com a noção de cultura de pares, vinda dos estudos da infância e com as redes educativas, vinda dos estudos com os cotidianos, que andamos a pensar nos candomblés brasileiros.

Em consonância com nossa abordagem interpretativa, defino cultura de pares infantis como um conjunto estável de atividades ou rotinas, artefatos, valores e preocupações que as crianças produzem e compartilham em interação com as demais. (CORSARO, 2011, p. 128).

Em seu "Ensaio sobre a Cegueira", Saramago (1995) pediu: "se podes olhar vê, se podes ver, repara". Reparar é um ato político. Escolhemos reparar as crianças de terreiros como sujeitos ativos de imensos conhecimentos. E, quando reparamos nessas crianças, sabemos que escolhemos pesquisar com um dado recorte de raça e de classe (entendendo raça como um conceito político). Essa escolha reinventou nosso modo de olhar e fazer pesquisa. Também ampliou nosso olhar para fora dos terreiros, pois, se assumimos que as crianças de terreiros são protagonistas de nossos estudos, não poderíamos deixar de olhar para a escola já que, a maioria das crianças de terreiros, olha, sente, percebe e vive a escola como um espaço discriminador.

Se nosso grupo de pesquisa também estuda: racismo religioso, laicidade, ensino religioso, foi porque as crianças de terreiros nos fizeram olhar para essas questões. É por isso que, desde o início, nosso olhar nasce multirreferencial. O grande mérito do argumento formativo da multirreferencialidade, segundo Macedo (2014) é ter a heretogeneidade como ponto de partida.

Sabemos que os Estudos com Crianças de Terreiros fundaram um campo novo de estudos para o qual seriam necessárias novas formas de fazerpensar, incluindo novos autores nem sempre vistos por olhos tão eurocentradamente acostumados. Mais uma vez estamos afinados com o que Alves propõe no segundo movimento das pesquisas com os cotidianos: "virar de ponta cabeça" (2008, p. 17). Não dizemos que nosso modo é "o certo", muito menos "o único", é apenas o nosso caminho praticado, caminho vivenciado.

Também não assumimos esse caminho como um método. Qualquer método rígido fracassaria diante do inesperado, do repentino da própria inventividade dos cotidianos de terreiros, sobretudo, quando compartilhado com as crianças. Crianças que não cabem em qualquer rascunho etnográfico nem mesmo na descrição pretensamente finalizada. Elas são muito mais do que 
dizemos, escrevemos e fotografamos (ainda que julguemos fazer pesquisa com elas). É por isso que sugerimos um abeiramento para que possamos entender que, mesmo mergulhando nesse campo e em seus conhecimentos, não sairemos de sua beira. E a beira já é um bom lugar para estar.

É desse lugar que habitamos que continuaremos afirmando que os Estudos com Crianças de Terreiros são fundamentais para a compreensão não só das infâncias no Brasil, mas também para a compreensão de nossa educação e sociedade.

\section{1 - Ifá àyá - oráculo interior}

Ou sobre ética nas pesquisas com crianças

Quem autoriza a participação da criança? seu nome? sua gravação? a fotografia? São questões levantadas por Kramer (2002) quando aborda complexamete que, se a autorização quem dá é o adulto, e não a criança, cabe indagar e mais uma vez, diz ela, quem é o sujeito da pesquisa? "Autoria se relaciona à autorização, à autoridade, e à autonomia. Pergunto: como proteger e ao mesmo tempo garantir autorização? Como resolver esse impasse?". (p. 53). As preocupações de Kramer sempre foram e continuam fundamentais ao nosso grupo, sobretudo porque pesquisamos com fotografias.

Mais recentemete, (Fernandes, 2016) defendeu que falar de ética na pesquisa com crianças é muito mais que ter cuidados no planejamento das pesquisa, "implica, sobretudo, atender aos modos como desencademos processos dialógicos e ponderados, de forma que se possa respeitá-las ontologicamente em sua alteridade" (p.775). No específico da autorização, sim, reunimos a autorização dos pais e sim, as crianças também autorizam ou não a entrevista e a fotografia ${ }^{19}$. No entanto é mais que isso e seríamos irresponsáveis se encerrássemos a questão nesse espaço.

Há um sem fim de cuidados fundamentais. Em yorùbá, talvez a expressão que mais se aproxime da palavra ética seja Ifá àyá, ou nosso oráculo interior, diálogo interno. Esse diálogo interno permamente é tanto do pesquisador consigo mesmo, como com seu grupo e com todos os envolvidos na pesquisa. Esse Ifá àyá afirmamos como indispensável sem o qual não podemos fazer o que fazemos, pesquisar o que pesquisamos.

\footnotetext{
${ }^{19}$ Sobre autorizações ver: Ferreira (2010).
} 


\section{2 - Fotografar em ato}

Fotoetnopesquisa-formação

Qualquer pesquisador, cujo tema e questões sejam relacionados ao candomblé, conhece o trabalho de Pierre Verger, ainda que não fotografe. Se, contudo, a pesquisa desenvolvida utiliza a fotografia como parte da etnografia, o trabalho desse pesquisador francês é referência e inspiração. Durante muito tempo li os textos de Verger, mas foi de tanto olhar suas fotografias que percebi um silenciamento. Verger fotografou crianças nos cultos que tanto amou, seja no Brasil, África ou Cuba, ainda que não muitas. A etnografia de Verger e sua fotografias seguiam muito bem, mas, se inseriam na falta de interesse da antropologia pelas crianças de um modo geral, já notada por Hirschfeld (2002), por exemplo.

No documentário "Janela da Alma" (2001), o cineasta alemão Wim Wenders disse que prefere usar óculos a lentes de contato, porque a armação dos óculos o ajuda a enquadrar o que ele quer ver, a selecionar as informações: "sem os óculos tenho a impressão de ver demais", afirma. Eu o entendo. Já me habituei a olhar pelo viewfinder, o visor da câmera fotográfica. Debruço meu olho ali e o mundo passa estranhamente a fazer sentido.

Macedo (2014) em diálogo com Baktin (2003), resgata o entendimento de ato como agir humano, ação situada, a que é atribuído ativamente um sentido no momento mesmo em que é realizada. Com o mesmo autor russo, Macedo compartilha a ideia de ato como o elemento que realiza a potência que o originou, destacando o processo como transformação constitutiva da potência em ato. O ato responsável, concorda ele, envolve o conteúdo do ato, seu processo, unindoos à valorização do agente com respeito a seu próprio ato, vinculada ao pensamento participativo. "O ato, portanto, postula, cria". (MACEDO, 2014, p. 46)

Vejo em retângulo fotográfico e, repetindo Wenders, prefiro assim. Quando decido debruçar o olho esquerdo no pequeno retângulo fotográfico eu fecho o olho direito. Escolho e excluo, 
componho e crio. Fotografo em ato. ${ }^{20}$ Mirar as crianças de terreiros é ação situada, atribuída de sentido, no momento em que é realizada (e mesmo quando antes é imaginada e buscada). Mirada que realiza a potência que a originou, e que sim destaca o processo como transformação constitutiva dessa potência em ato. Fotografo em ato.

Fotografar em ato sempre aciona questões, desde seu processo. Em ato, reúne escolhas e, como escolher é excluir, também implica, como disse, exclusões. O que entra no foco? Como compomos? Só para uma conversa ligeira (que poderemos aprofundar depois), falemos de plongée e contra contra-plongée, por exemplo. As duas ideias remetem ao termo francês que equivale a "mergulho", em português. Na primeira se filmamos ou fotografamos a pessoa de cima para baixo, transmitimos a ideia de inferioridade do que está sendo filmado. Em oposto, no contraplongée, a câmera fíca abaixo do nível dos olhos dos personagens, voltada para cima. O enquadramento, conhecido como câmera baixa, coloca a pessoa fotografada acima do espectador. Com um ou com outro ato destacamos como vemos a pessoa fotografada e mais: como ela vai ser vista, se vê e nos vê e nos resultados de nossos atos fotográficos.

$\mathrm{Na}$ maioria de minhas fotografias em ato, procuro ou ficar no mesmo nível da criança fotografada ou abaixo dela. Não digo que nunca fiz um plongée, mas toda vez que fiz, em função de uma escolha estética, tinha consciência do que essa "simples escolha estética", significava.

Também temos acionado a fotografia no sentido do que Santos (1996) chama de imagens desestabilizadoras. Por isso, acrescento, penso as fotografias que fazemos como imagens descoloniais porque desacostumam lugares acostumados na lógica dominante da colonialidade: adultocêntrica, racista, branca, cristã.

Nos inspiram então, o diálogo que podemos continuar com Macedo, tanto com a etnopesquisa-ação, como a etnopesquisa-formação (2010).

Falar de uma etonopesquisa-ação nos conduz a um campo onde a academia concretamente sai de seus muros e age em termos de intervenção com as pessoas. Na relação etopesquisa/ação, assume-se como principal objetivo da pesquisa a solidariedade e a ética comunitárias. (MACEDO, 2010, p. 156).

Quando olhamos para nossa caminhada, nos damos conta de que cada foto produzida, cada filme que fazemos já foi (e continuara sendo) usado em audiências públicas para denunciar o racismo, incluindo sua face religiosa, em cursos de formação de professores, exposição em escolas, exibições de rua.

\footnotetext{
${ }^{20}$ E para seguir, mais tarde, o diálogo com Macedo e seus atos de currículo. Posso dizer também que penso a também a fotografia como atos de currículo.
} 
Para nosso grupo, não há pesquisa sem a discussão permamente com os interlocures que indicam problemas, novas questões, caminhos e nossa própria conduta como pesquisadores. É por isso também dialogamos com a etnopesquisa-formação:

$\mathrm{Na}$ formulação da problemática de uma etnopesquisa-formação, o preocesso se dá no interior de um problema social e envolve uma necessidade social que preocupa um grupo em dado contexto. O pesquisador implica-se junto com a coletividade na construção da problemática da pesquisa e de seu estudo. (MACEDO, 161)

\section{3 - Caderno de memória dos nossos olhos}

Itinerâncias Kékeré

Faz tempo que escrevo e fotografo, por isso, anoto nos cadernos de campo o que vejo sem elas, mas também anoto o que vi e vejo com todas as minhas Canons (da analógica às digitais) e com meus smartphones. Nos cadernos guardo letras, jasmins, penas de galinha, fotografias que ganho, fiapos de màrìwó (desfiadinhos de folhas de dendezeiro), desenhos das crianças, infinidades de descrições, interpretações, retalhos teóricos, poemas, rezas, planos, telefones, endereços, calendários e infinidades de tudo e de mim mesma. Pelo afeto dessa prática e porque acredito criálas sempre na relação com as pessoas no campo de pesquisa, em especial com as crianças, chamo minhas notas de caderno de memória dos nossos olhos. Em yorùbá seria: Kosílè Iyè nú ojú tiwa.

Em 2012, criei uma página no Facebook com o nome de "Educação nos Terreiros" (título do livro de Caputo, publicado no mesmo ano). O objetivo era compartilhar falas e fotografias de crianças de diversos terreiros pelo Brasil, notas e impressões. Para Santos (2014) o suporte material fez com que durante muito tempo a escrita do diário ficasse restrita ao mundo privado do autor e a transição do suporte midiático para o digital permite o compartilhamento e a interação. E permite mesmo, já desde a criação do novo dispositivo de pesquisa, a interação com os sujeitos envolvidos foi ampliada atingindo maiores dimensões.

Por agora, atuando e pensando nas abordagens do diarismo no contexto da cibercultura ${ }^{21}$, refletindo sobre as distinções entre Diário de Campo e Jornal de Pesquisa (JP) trazidas por Veloso (2017) assumo que nos dispositivos que uso (tanto o material como o digital) reúno narrativas e diálogos com os sujeitos de pesquisa, reflexões teóricas, reações afetivas, inacabamentos, subjetividades, dilemas, contendas, poemas. Faço isso tanto na página pública como nos meus

\footnotetext{
${ }^{21}$ Cibercultura é a cultura contemporânea que se estrutura pela mediação das tecnologias digitais em rede, seus artefatos sócio técnicos e culturais em interação com seres humanos em processos de comunicação na interface cidade/ciberespaço (Santos, 2017, p. 9).
} 
cadernos de campo privados. A página é aberta e tem atualmente mais de 16 mil não apenas seguidores, mas imaginantes (Sant'Anna e Caputo, 2018) que nela interagem com frequência. Pode ser chamada de Jornal de Pesquisa, se preferirem e acharem adequado. Acho mesmo que se insira nessa abordagem. Contudo, nesse momento, continuarei disponibilizando-a como um Fotoetonocarderno compartilhado ${ }^{22}$. É fotoetnocaderno porque mobiliza a fotografia com crianças na etnografia, nas reflexões, nas autoreflexões de nosso próprio fazer etnográfico e nas narrativas. É compartilhado porque, desde o início, disponibilizamos publicamente o que fazemos para oportunizar o debate entre os sujeitos dos terreiros em especial, as crianças, suas famílias, suas comunidades e entre outros terreiros. Além disso optamos pela pesquisa aberta, imaginando diálogo e trocas com outros pesquisadores e pesquisadoras. Por fim é ainda caderno de itinerância ${ }^{23}$. Acredito que chamar a página de Jornal de Pesquisa a distanciaria um pouco e prefiro continuar disponibilizando-a como um caderno porque o caderno eu carrego por aí junto do meu okàn (coração). Talvez o que direi agora explique um pouco mais minha opção.

No mundo em redes educativas de Alves (2010), a educação acontece em rede e todos os espaçostempos ensinam, inclusive as rodas de samba. Outra noite, em uma roda de samba no Rio Comprido, conversava com o Bàbáláwo ${ }^{24}$, professor e escritor Luiz Antonio Simas, quando ele me disse ter ouvido do Bàbáláwo e pesquisador Wande Abimbola o seguinte: "entrega tua disponibilidade a Orunmilá25 e ele te devolverá um poema ${ }^{26 " . ~ G u a r d a m o s ~ a ~ f r a s e ~ c o m o ~ c o n s e l h o ~ e ~}$ metáfora de pesquisa. Se continuarmos a entregar nossa disponibilidade aos Estudos com Crianças de Terreiros, continuaremos, com sorte, praticando nossa fotoetnopoética kékeré, nossa fotoetnopoética miúda. Talvez, com sorte também, ela continue nos devolvendo fotoetnopoemas, como esse, de Mikaela de Carvalho Reis, de 3 anos, do Ilè Aṣé Omi Laare İyá Sagbá.

\section{"Yemanjá é esse mar beeem grande, dentro desse peixe pequeno"}

Fotoetonopoema devolvido: considerações finais

\footnotetext{
${ }^{22}$ Não faria essa discussão sem a professora Edméa Santos, interlocutora privilegiada. Sem o doutorando do Kékeré Ataíde Junior, interlocutor cotidiano. Sem a igualmente integrante do Kékeré, Máira Pereira, que conceituou Fotodiário online como diário de campo constituído como grupo fechado no Facebook em sua tese de doutoramento (2018). Os dispositivos usados por cada uma de nós guardam semelhanças e diferenças fundamentais, que, certamente, trarão construibuições para novas discussões.

${ }^{23}$ Itinerância é um percurso que se faz pouco a pouco, de maneira inacabada, no emaranhado dos vários itinerários percorridos por uma pessoa ou grupo. (BARBIER apud SANTOS, 2014).

${ }^{24}$ Pai do segredo. Sacerdote do culto de Ifá encarregado da consulta oracular. (Jagun, 2017, p. 546).

${ }^{25}$ Divindade. Senhor de Ifá (sistema divinatório). (Jagun, 2017, pgs 169 e 185).

${ }^{26}$ Quem conhece, ao menos um pouco o assunto, sabe que ele se refere ao sistema de mundo e sistema oracular de Ifá que fala através de poemas.
} 


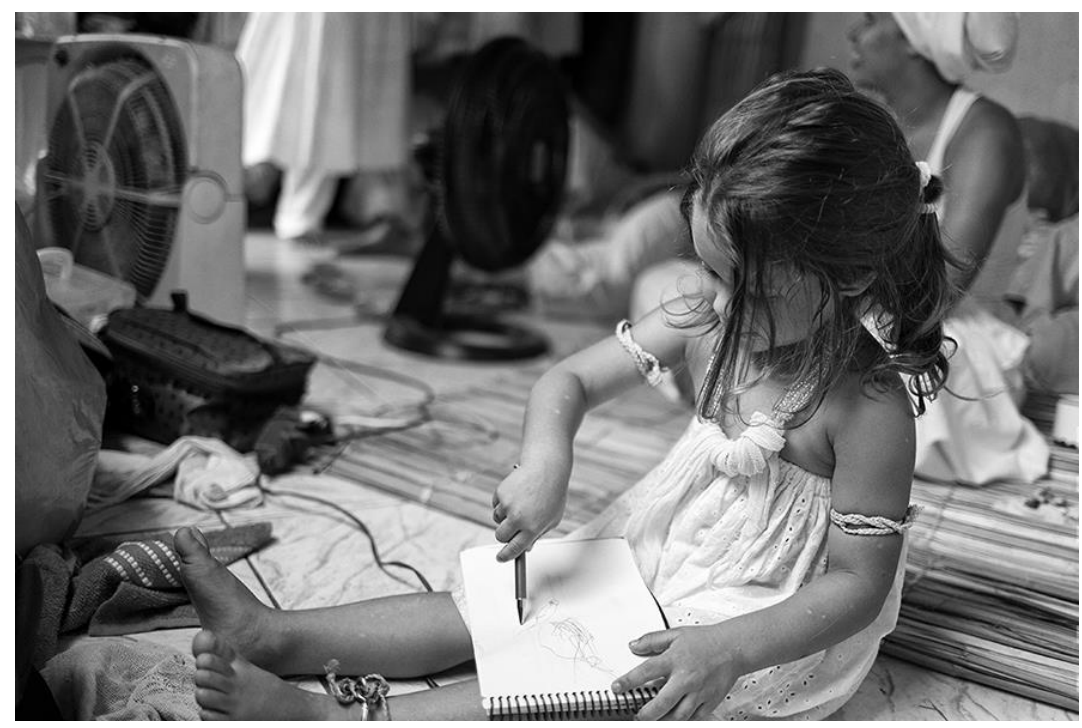

- Estou desenhando Yemanjá.

-Yemanjá é esse peixe grande Mikaela?

- Não, isso é uma baleia.

- Ah sim.. Yemanjá é esse outro peixe?

- Nãooo, isso é um peeixe tubarão.

- Então... o que é Yemanjá?

E, enquanto Mikaela, vai circulando a caneta pela folha do meu caderno de campo, responde:

-Yemanjá é esse mar beeem grande, dentro desse peixe pequeno. Bem pequeno. É isso Yemanjá é um mar beem grande, dentro de um peixe pequeno. Entendeu?

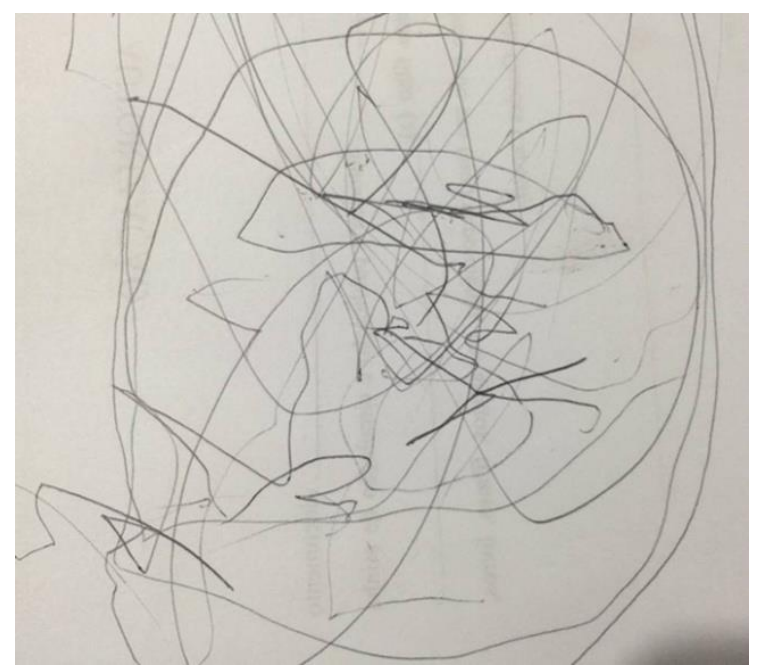

\section{Referências Bibliográficas}


ALVES, Nilda. Sobre Movimentos das Pesquisas nos/dos/com Cotidianos (2008). In: OLIVEIRA, Inês Barbosa; ALVES, Nilda (ogs). Pesquisa nos/dos/com os cotidianos das escolas. Petrópolis: DP et Alli, 2008. maio/junho/julho/agosto, 2003.

Cultura e cotidiano escolar. Revista Brasileira de Educação, número 23,

BÂ, Amadou Hampâté. A tradição viva. In: História Geral da África. Volume 1. São Paulo, Unesco e Cortez: 2010.

BENISTE, J. Dicionário Yorùbá Português. Rio de Janeiro: Bertrand Brasil, 2009.

CAPUTO, Stela G. Educação em terreiros de candomblé - contribuição para uma educação multicultural crítica. In: CANDAU, Vera Maria. Educação Intercultural e cotidiano escolar. Rio de Janeiro: 7 Letras, 2006.

. Educação nos terreiros - e como a escola se relaciona com crianças de candomblé. Rio de Janeiro: Pallas, 2012.

Pesquisar com crianças em terreiros: diálogos e alianças necessárias. In: CANDAU, Vera M. (Org.). Interculturalizar, descolonizar, democratizar: uma educação "outra"? Rio de Janeiro: 7 Letras, 2016.

CASTILLO, Lisa Earl. Entre a oralidade e a escrita - a etnografia nos candomblés da Bahia. Salvador: EDUFBA, 2010.

CORSARO, William, A. Sociologia da Infância, Porto Alegre: Artmed, 2011.

FERNANDES, Natália. Ética com crianças: ausência e desafios. In: Revista Brasileira de Educação. ANPED, Rio de Janeiro: 2016.

FERREIRA. Manuela. "Ela é nossa prisioneira!" - Questões teóricas, epistemológicas e ético-metodológicas a propósito dos processos de obtenção da permissão das crianças pequenas numa pesquisa etnográfica. In: Revista Reflexão e Ação, Santa Cruz do Sul: 2010.

HIRSCHFELD, Lawrence A. Why Don't Anthropologists Like Children. In: American Anthropologist, 2002.

JAGUN,M. Orí: a cabeça como Divindade. Rio de Janeiro: LITTERIS, 2015.

. Vocabulário Temático do Candomblé. Rio de Janeiro: LITTERIS, 2017.

KRAMER, Sônia. Autoria e Autorização: questões éticas na pesquisa com crianças. Cadernos de Pesquisa, n. 116, julho, 2012.

MACEDO, R. S. Atos de Currículo Formação em Ato? Salvador: Editus, 2014. Etnopesquisa crítica, Etnopesquisa-Formação. Brasília: Liber Livro, 2010.

PEIRANO, Mariza. Etnografia não é método. In: Horizontes Antropológicos, Porto Alegre: 2014.

PEREIRA, Máira Conceição Alves. Redes Educativas no Terreiro Ilè Omidayè: uma pesquisa com os cotidianos na cibercultura. Tese (Doutorado em Educação). Orientação: Stela Guedes Caputo. PROPED/UERJ, Rio de Janeiro, 2018.

PESSOA DE BARROS, José Flávio. A Floresta Sagrada de Ossaim - o segredo das folhas. Rio de Janeiro: Pallas, 2011. 
RISÉRIO ANTONIO, Oriki Orixá. São Paulo: Editora Perspectiva, 1996.

SÀLÁMÌ, Síkírù; RIBEIRO, Íyakemi Ronilda. Exu e a Ordem do Universo. São Paulo: Oduduwa, 2011.

SANTOS, Boaventura Sousa. Para Uma Pedagogia do Conflito. In: SILVA, L.H; AZEVEDO, J.; SANTOS, E. (orgs.). Reestruturação Curricular: novos mapas culturais. novas perspectivas educacionais. Porto Alegre: Sulina, 1996.

SANTOS, Edméa (org). Diário Online: dispositivo multirreferencial de pesquisa formação na cibercultura. Portugal: Whitebooks, 2014.

SANTOS, Juana Elbein. Os nagôs e a morte. Petrópolis: Vozes, 1986.

SARMENTO, Manuel; GOUVEA, Maria Cristina Soares. Estudos da Infância, Educação e Práticas Sociais. Petrópolis: Vozes, 2008.

SANT'ANNA, Cristiano; CAPUTO, Stela. Ninguém é seguidos, somos todos imaginantes. In: Educação, Comunicação, Cultura e Diferença. Vitória: Pedregulho, 2018.

SIMAS, Luiz Antonio; RUFINO, Luiz. Fogo no mato, a Ciência Encantada das Macumbas. Rio de Janeiro: Móruloa, 2018.

VELOSO, M. M. S. A; BONILLA, M.H. O Jornal de Pesquisa e o Diário de Campo como Dispositivos da Pesquisa-Formação. In: Revistas Interfaces Científicas. N. 1, Vol. 6. Aracaju: EDUNIT, 2017

VERGER, Pierre Fatumbi. Orixás. Salvador: Corrupio, 2002. 


\section{RESUMO}

"O terreiro é o mundo ficando mais bonito", diz Mene Viana Cardoso, de 3 anos, do Ilê Axé Omi Laare İyá Sagbá, um terreiro de candomblé, em Santa Cruz da Serra, Duque de Caxias, na Baixada Fluminese. Os terreiros, entre eles, os terreiros de candomblé, preservaram e ressignificaram modos de vida trazidos do Continente Africano durante a escravização. Conhecimentos sofisticados que atravessaram o Atlântico e foram mantidos e reinventados nesses espaçostempos. Os Estudos com Crianças de Terreiros nascem de duas grandes negações, ou de dois grandes desprezos: o primeiro desprezo é herança hegemônica deixada pelo modo dominante com o qual a modernidade "via" os cotidianos, tidos como lugar de reprodução de saberes menores. O segundo grande desprezo é aquele que marca concepções e abordagens sociológicas que negam a criança como sujeito de conhecimento e participação social, portanto silenciando-as.Em um caminho original, o Grupo de Pesquisa Kékeré (pequeno em yorubá) contraria essa dupla negação para inverter e afirmar que, justamente aquilo que é considerado menor (os cotidianos), e quem é considerado menor ainda (as crianças), são fundamentos vitais para compreender a sociedade em que vivemos, bem como desestabilizar suas lógicas coloniais profundas. A proposta desse artigo é apresentar algumas notas dos caminhos escolhidos para nossos estudos.

Palavras chave: Estudos Com Crianças de Terreiro. Criança. Infância. Pesquisa com os cotidianos.

\section{OBSERVING CLOSELY, TO NARRATE KÉKERÉNOTES ON OUR PHOTOETNOPOETICS WITH CHILDREN FROM TERREIROS}

\section{ABSTRACT}

"The terreiro is the world becoming more beautiful," says Mene Viana Cardoso, 3 years old, from Ilê Axé Omi Laare İyá Sagbá, a candomblé terreiro, in Santa Cruz da Serra, Duque de Caxias, in Fluminense Lowland. The yards, among them, Candomblé yards (terreiros), preserved and re-signified lifestyles brought from the African Continent during enslavement. Sophisticated knowledge that has crossed the Atlantic and been maintained and reinvented in these space-times. Studies with Terreiros' Children are born from two great negations, or from two great contempts: the first contempt is a hegemonic heritage left by the dominant way in which modernity "considered" the quotidian as a place for reproduction of lower knowledge. The second great contempt is one that marks sociological conceptions and approaches that deny children as a subject of knowledge and social participation, thus silencing them. In an original path, the Kékeré (small in Yoruba) Research Group opposes this double negation in order to reverse and state that, exactly what is considered small/less important (quotidian life) and those who are considered even smaller/less important (children) are vital foundations for understanding the society in which we live, as well as destabilize their deep colonial logic. The purpose of this article is to present some notes of the paths chosen for our studies.

Keywords: Studies With Terreiro's Children. Child. Childhood. Research with quotidian.

\section{MIRAR PEQUEÑO, DECIR KÉKERÉ NOTAS A CERCA DE NUESTRA FOTOETNOPOÉTICA CON NIÑOS DE TERREIROS}

\section{RESUMEN}

"El terreiro es el mundo más hermoso", dijo Mene Viana Cardoso, de 3 anos, do Ilê Axé Omi Laare İyá Sagbá, un terreiro de candomblé, en Santa Cruz da Serra, Duque de Caxias, en Baixada Fluminese. Los terreros, entre ellos, los terreros de candomblé, preservaron y resignificaron modos de vida traídos del continente africano durante la esclavización. Conocimientos sofisticados que atravesaron el Atlántico y fueron mantenidos y reinventados en esos espaciostempos. Los estudios con niños de terreros nacen de dos grandes negaciones, o de dos grandes desprecio: el primer desprecio es herencia hegemónica dejada por el modo dominante con el que la modernidad "veía" los cotidianos, tenidos como lugar de reproducción y saberes menores. El 
segundo gran desprecio es aquel que marca concepciones y abordajes sociológicos que niegan al niño como sujeto de conocimiento y participación social, por lo tanto silenciándolos. En un camino original, el Grupo Kékeré (pequeño en yorubá) contradice esta doble negación para invertir y afirmar que, justamente aquello que es considerado menor (los cotidianos), y quien es considerado menor aún (los niños), son fundamentos vitales para comprender la sociedad en que vivimos, así como desestabilizar sus lógicas coloniales profundas. La propuesta de este artículo es presentar algunas notas de los caminos de esos estudios.

Palabras-clave: Estudios con Niños de Terreiro. Niño. La infancia. Estudios con los cotidianos. 